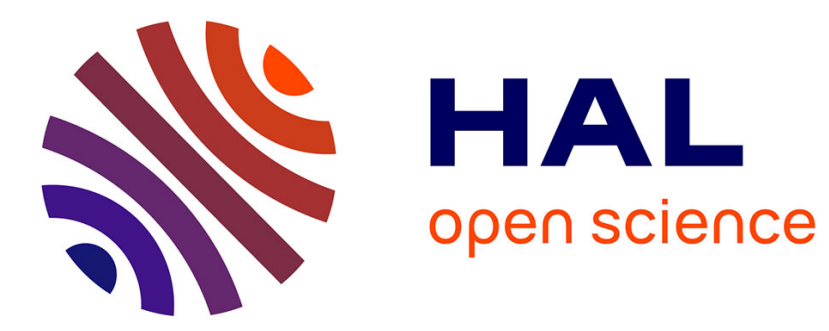

\title{
Does Exchange Rate Control Improve Inflation Targeting in Emerging Economies? \\ Marc Pourroy
}

\section{To cite this version:}

Marc Pourroy. Does Exchange Rate Control Improve Inflation Targeting in Emerging Economies?. Economics Letters, 2012, 116 (3), pp.448-450. 10.1016/j.econlet.2012.04.036 . hal-02619540

\author{
HAL Id: hal-02619540 \\ https://hal.science/hal-02619540
}

Submitted on 25 May 2020

HAL is a multi-disciplinary open access archive for the deposit and dissemination of scientific research documents, whether they are published or not. The documents may come from teaching and research institutions in France or abroad, or from public or private research centers.
L'archive ouverte pluridisciplinaire HAL, est destinée au dépôt et à la diffusion de documents scientifiques de niveau recherche, publiés ou non, émanant des établissements d'enseignement et de recherche français ou étrangers, des laboratoires publics ou privés. 


\title{
Does Exchange Rate Control Improve Inflation Targeting in Emerging Economies?
}

\author{
Marc Pourroy ${ }^{7}$
}

\begin{abstract}
:
Based on an original de facto classification of the exchange rate regimes, this paper provides strong evidence that hybrid inflation-targeting frameworks, in which the exchange rate is managed, deliver a stronger nominal anchor, as they better resisted the 2007-2008 inflation shock.
\end{abstract}

\section{Highlights:}

- Two frameworks for inflation-targeting in emerging economies: inflation-targeting strategies with free-floating exchange rates and inflation-targeting strategies with managed floating.

- Inattention to the Taylor Principle by both of the two groups during the 2007-2008 price shock.

- IT strategies with managed floating strongly associated with a weaker inflation surge, less deviation from the target, and less credibility loss.

\section{JEL classification:}

E31, E40, E58, F31.

\section{Keywords:}

monetary policy, inflation-targeting, exchange rate, 2007-2008 inflation shock.

\footnotetext{
${ }^{1}$ Affiliation : Centre d'Économie de la Sorbonne, Université Paris 1 Panthéon-Sorbonne Postal: 106-112 boulevard de l'Hôpital 75647 PARIS Cedex 13, FRANCE

Email: marc.pourroy@univ-paris1.fr

Phone: +33 144078277
} 


\section{Introduction}

Inflation targeting (IT) is a monetary framework whose nominal anchor is based on price stability. The Central Bank (CB) was first thought of as an "inflation nutter" (King, 1997) that cannot control any variable other than prices without losing its credibility and endangering the monetary anchor. Svensson (1999) first spoke of flexible IT, as opposed to strict IT, because "the 'target variables' of the central bank include not only inflation but other variables as well, such as the output gap" (Svensson (2010), page 13). A new step was taken by García et al. (2009), who spoke of "Hybrid Inflation-Targeting regimes" (HIT), in which the exchange rate is included in the CBs' reaction functions.

In an important work, García et al. (2009) systematically study HIT regimes. Their taxonomy included the Open Economy IT framework, as in Cavoli and Rajan (2006), and Natalucci and Ravenna (2008); IT with Exchange Rate Band, as in Lahiri and Vegh (2001) and Moron and Winkelried (2005); and Exchange-Rate-Based IT, as in McCallum (2006). García et al. (2009) propose a DSGE (Dynamic Stochastic General Equilibrium) model to study all types of IT rules: plain vanilla IT as well as all HIT rules. They concluded that emerging economies (EES) "are especially likely to benefit from some exchange rate smoothing because of the perverse impact of exchange rate movements on activity" (page 2).

The purpose of this letter was to test empirically whether or not exchange rate management improves IT, that is, does exchange rate management help the CBs to achieve their targets? Does it impact the CBs' credibility? Does it reduce the Taylor curve output/inflation volatility trade-off? In response to these questions, I carefully studied the reaction of 16 fully fledged inflation-targeting emerging economies (ITEEs) to the 2007-2008 inflation shock. This shock is a perfect example of an exogenous shock on prices that appeared on a worldwide scale. Furthermore, IT is a recent monetary policy framework; it was adopted by central banks during the early 2000s. Thus, it was the first price shock that these central banks had to deal with.

The letter is structured as follows. In Section 2, I briefly describe my methodology and data. Section 3 sets out my results. The final section provides a brief conclusion.

\section{Methodology}

\subsection{Free Floating or Hybrid Inflation Targeting?}

I submitted 16 inflation-targeting emerging economies (ITEEs) to the clustering analysis method of Levy-Yeyati and Sturzenegger (LYS, 2005) in order to obtain a de facto classification of their monetary policy. This method groups the cases according to similarity in the behavior of the three reference variables: changes in the nominal exchange rate $(\sigma(\Delta \mathrm{e}))$, 
the volatility of these changes $(\sigma(\Delta e))$, and the volatility of international reserves $(\sigma(\Delta r))$. We added nine countries to the sample, as indicators of the two polar policies: free floating is represented by Australia, Canada, the USA, and Japan, and peg is represented by Croatia, Hong Kong, Kazakhstan, Kuwait, and Vietnam. I ran the K-means algorithm over the four stable years before the shock, that is 2002-2006. Nine ITEEs out of 16 countries were in the same cluster as the free floating indicators. This result indicates that these countries share the same de facto exchange rate regime. I considered these countries to be Free Floating Inflation Targeters (FFIT). These countries were Brazil, Chile, Colombia, Hungary, Indonesia, Poland, South Africa, and Turkey. One country was in the same cluster as the countries taken as indicators of peg: Peru. The remaining six countries, the Czech Republic, Israel, Mexico, the Philippines, the Slovak Republic, South Korea, and Thailand, formed a third cluster between the two polar groups; this was the managed float cluster (or dirty float cluster). Thus, I could divide my ITEE sample into two subgroups: Free Floating Inflation Targeters (FFITs) and Hybrid Inflation Targeters (HITs).

\begin{tabular}{|l|rrr|}
\hline & \multicolumn{1}{|c}{$\sigma(\mathrm{e})$} & $\sigma(\Delta \mathrm{e})$ & \multicolumn{1}{c|}{$\sigma(\mathrm{r})$} \\
\hline Free Floating & 2,23 & 2,68 & 4,5 \\
Dirty Float & 1,32 & 1,61 & 7,84 \\
Fixed & 0,35 & 0,44 & 3,78 \\
\hline
\end{tabular}

Table 1: Centroid values

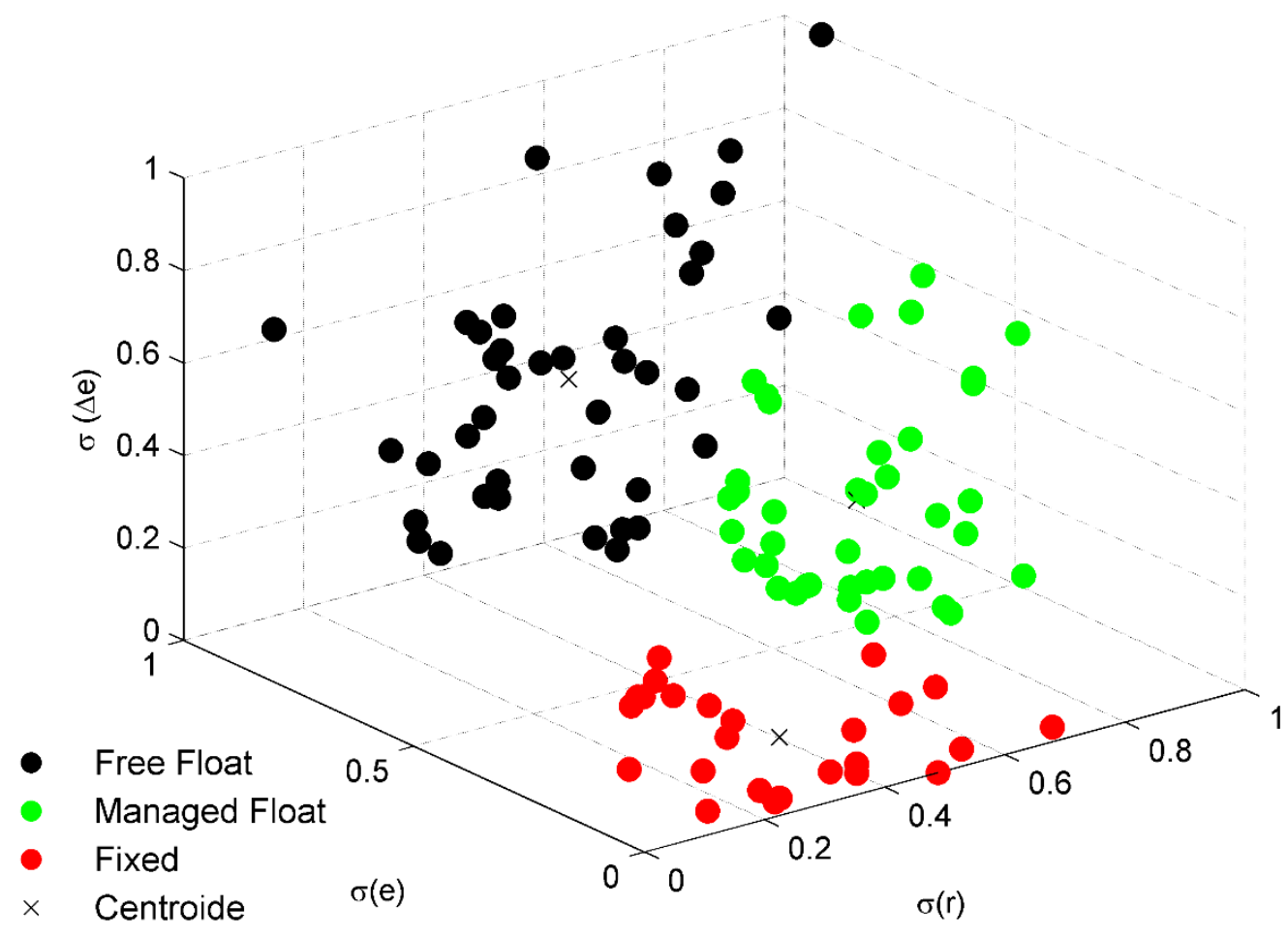

Figure 1: Relative position of the three clusters. 


\subsection{Diffs-in-diffs analysis}

I compared the performance of the FFIT countries with that of the HIT countries during the 2007-2008 price shock to determine whether or not control matters.

I used Ball and Sheridan's "Diffs-in-Diffs" strategy to determine the effect of exchange rate control on economic variables while considering the problem of correlation between the benchmark pre-period variable and the dummy variable. The mean reversion problem was also taken into account.

Here, $\mathrm{X}$ denotes any economic variable, such as average inflation, excess inflation, credibility, real interest rate, inflation volatility or output variability. The pre subscript indicates the time period before the inflation shock, and the post subscript indicates the time period after the shock. $D$ is a dummy variable, taking a value of 0 if the country is FFIT and a value of 1 if the country is HIT. This equation measures the difference in the average inflation rate (for instance) between the two time periods (post minus pre) as the function of the IT framework (dummy variable $\mathrm{D}$ ) and the average inflation rate of the pre-shock period's average inflation.

\subsection{Data and selection of time periods}

The pre-period ranged from the first quarter of 2004 to the last quarter of 2006. I could not start the pre-period before 2004 because only a few EEs were IT in the early 2000s. The postperiod started in the second quarter of 2007, when the inflation pressures appeared (see Giustiniani et al. (2009)). I ended the post-period in the third quarter of 2008 in order not to include the consequences of the Lehman's bankruptcy. I used quarterly data from IMF IFS and Data-Stream. I tested many different settings, and the results are strong. Data are available from the author.

\section{Results}

\subsection{Taylor principle}

The OLS estimation of equation 1 , with $X$ denoting the real interest rate, shows that on average the FFITs real interest rate dropped by almost 100 bp ( $00=-0.99$, $p$-value $<10 \%)$. The dummy variable was associated with a positive but not strong coefficient $(a 1=0.62, p$ value $>10 \%$ ), meaning that the real interest rate of HITs failed in the same proportion as it did for FFITs. 
Equation 2 (last column) reveals that this drop in the real interest rate was strongly and positively correlated with the pre-period level. CBs that had low real interest rates before the shock reacted faster and stronger than the others.

In the two groups of countries, the decline in the real interest rate shows that CBs did not raise their nominal rates faster than inflation. Thus, none of the CBs applied the Taylor Principle.

\subsection{Target achievement}

I used two alternative definitions of price dynamics: inflation (change in the Consumer Price Index) and excess inflation (deviation of inflation from the CB's target).

The impact of the inflation shock on inflation was less important in HITs: a1 had a negative value with a strong $p$-value when corrected by the pre level period (in equation 2, a1 $=-1.87$, p-value $<1 \%$ ).

As for inflation, the shock had a smaller effect on excess inflation in HITs than in FFITs. The estimated coefficient a1 had a negative value with a strong $p$-value when corrected by the pre level period $(\mathrm{a} 1=-1.30, \mathrm{p}$-value $<10)$.

Credibility was calculated as the difference between the CB inflation target and the expected inflation rate given by the WES survey. The estimation of both equations gave strong results. FFIT credibility dropped by $1.70 \mathrm{pp}$ with the shock. HIT credibility fell, on average, by $1.18 \mathrm{pp}$ less than FFIT credibility did (estimation of a1 in equation $1, p$-value $<5 \%$ ).

Our results seem to indicate that exchange rate control contributed to limiting the extent to which the inflation rate, excess inflation, and credibility worsened. This result suggests that HITs had a better monetary anchor than FFITs.

\subsection{Efficiency curve}

The efficiency of a monetary policy is generally evaluated by the Taylor curve (see Svensson (2010)). The estimation of the two equations for the volatility of inflation and GDP gross (defined as the standard deviation) showed no strong support for any movement of the curve. 


\begin{tabular}{|c|c|c|c|c|c|c|c|c|c|c|c|c|c|c|}
\hline & \multicolumn{2}{|c|}{ Inflation } & \multicolumn{2}{|c|}{ Excess Inflation } & \multicolumn{2}{|c|}{ Credibility } & \multicolumn{2}{|c|}{$\sigma($ Inflation $)$} & \multicolumn{2}{|c|}{ (Excess Inflation } & \multicolumn{2}{|c|}{$\sigma$ (GDP Gross) } & \multicolumn{2}{|c|}{ Real Interest Rate } \\
\hline & (eq1) & (eq2) & (eq1) & (eq2) & (eq1) & (eq2) & (eq1) & (eq2) & (eq1) & (eq2) & (eq1) & (eq2) & (eq1) & (eq2) \\
\hline $\mathrm{col}$ & $\begin{array}{l}1.399 * \\
(.748)\end{array}$ & $\begin{array}{r}4.790^{* *} \\
(.825)\end{array}$ & $\begin{array}{c}2.316^{* * *} \\
(.668)\end{array}$ & $\begin{array}{c}2.755^{* * * *} \\
(.487)\end{array}$ & $\begin{array}{c}1.701^{* *} \\
(.407)\end{array}$ & $\begin{array}{c}2.024^{* * *} \\
(.510)\end{array}$ & $\begin{array}{l}-.024 \\
(.382)\end{array}$ & $\begin{array}{c}.179 \\
(.732)\end{array}$ & $\begin{array}{l}-.013 \\
(.470)\end{array}$ & $\begin{array}{r}2.146^{* *} \\
(.764)\end{array}$ & $\begin{array}{l}.839 * * \\
(.385)\end{array}$ & $\begin{array}{c}.031 \\
(.650)\end{array}$ & $\begin{array}{l}-.994^{*} \\
(.518)\end{array}$ & $\begin{array}{c}.031 \\
(.650)\end{array}$ \\
\hline dummy $\left(a_{1}\right)$ & $\begin{array}{c}-.645 \\
(1.058)\end{array}$ & $\begin{array}{r}-1.875^{* *} \\
(.694)\end{array}$ & $\begin{array}{l}-1.257 \\
(.944\}\end{array}$ & $\begin{array}{r}-1.309 * \\
(.669)\end{array}$ & $\begin{array}{c}1.182^{* *} \\
(.575)\end{array}$ & $\begin{array}{c}1.160^{* *} \\
(.574)\end{array}$ & $\begin{array}{l}.959 * \\
(.541)\end{array}$ & $\begin{array}{c}.839 \\
(.666)\end{array}$ & $\begin{array}{l}1.156^{\circ} \\
(.665)\end{array}$ & $\begin{array}{c}.019 \\
(.625)\end{array}$ & $\begin{array}{c}.436 \\
(.545)\end{array}$ & $\begin{array}{c}.312 \\
(.528)\end{array}$ & $\begin{array}{c}.628 \\
(.733)\end{array}$ & $\begin{array}{c}.312 \\
(.528)\end{array}$ \\
\hline $\operatorname{Xpre}\left(a_{2}\right)$ & & $\begin{array}{c}-.640^{* * *} \\
(.130) \\
\end{array}$ & & $\begin{array}{c}-.866^{* * *} \\
(.225) \\
\end{array}$ & & $\begin{array}{l}.470 \\
(.451)\end{array}$ & & $\begin{array}{r}-.066 \\
(.199) \\
\end{array}$ & & $\begin{array}{c}-.846^{* * *} \\
(.263) \\
\end{array}$ & & $\begin{array}{r}.581 \\
(.385) \\
\end{array}$ & & $\begin{array}{c}.581 \\
(.385) \\
\end{array}$ \\
\hline r2 & .026 & .661 & .112 & .586 & .232 & .291 & 183 & .19 & . 178. & .542 & .044. & 186 & .05 & 186 \\
\hline
\end{tabular}

Table 2: Results

\section{Conclusion}

My study clearly shows two distinct behaviors of emerging economies that have adopted an inflation-targeting framework: some have an independent floating exchange rate, whereas others have a managed float scheme. To our knowledge, this study is the first to provide strong evidence that the exchange rate strategy played a major role during the 2007-2008 price shock in ITEEs.

HIT is strongly associated with a weaker inflation surge, less deviation from the target, and less credibility loss.

Part of the explanation for this result comes from the inattention to the Taylor Principle by both of the two groups. Thus, IT effectiveness has to be questioned.

Here is a paradox: the most credible CBs are not those that did what they said they would; the most credible CBs are those who enlarged their toolkit with other goals and tools, with no clear communication about these actions. 


\section{References:}

Cavoli, T., Rajan, R.S., 2006. Inflation Targeting Arrangements in Asia: Exploring the Role of the Exchange Rate. National University of Singapore, Department of Economics, SCAPE Policy Research Working Paper Series 0603.

García, C., Restrepo, J., Roger, S., 2009. Hybrid Inflation Targeting Regimes. International Monetary Fund Working Paper 234.

Giustiniani, A., Habermeier, K., Jácome, L.I., Ishi, K., Kisinbay, T., Otker-Robe, I., Vávra, D., Vazquez, F., 2009. Inflation Pressures and Monetary Policy Options in Emerging and Developing Countries - A Cross Regional Perspective. International Monetary Fund Working Papers 1.

King, M., 1997. Changes in UK monetary policy: Rules and discretion in practice. Journal of Monetary Economics 39(1), 81-97.

Lahiri, A., Vegh, C.A., 2001. Living with the Fear of Floating: An Optimal Policy Perspective. National Bureau of Economic Research Working Paper Series 8391.

Levy-Yeyati, E., Sturzenegger, F., 2005. Classifying exchange rate regimes: Deeds vs. words. European Economic Review, 49(6), 1603-1635.

Mc Callum, B., 2006. MAS: Singapore's Exchange Rate-Centered Monetary Policy Regime and Its Relevance for China. MAS Staff Paper 43.

Moron, E., Winkelried, D., 2005. Monetary policy rules for financially vulnerable economies. Journal of Development Economics 76(1), 23-51.

Natalucci, F.M., Ravenna, F., 2008. Monetary Policy Choices in Emerging Market Economies: The Case of High Productivity Growth. Journal of Money, Credit and Banking 40(2-3), 243271.

Svensson, L.E.O., 2010. Inflation Targeting Handbook, in: Friedman, B., and Woodford, M. (Eds.), Handbook of Monetary Economics. North-Holland.

Svensson, L.E.O., 1999. Inflation Targeting: Some Extensions. Scandinavian Journal of Economics 101(3), 337-61. 